Institute of Russian History of the Russian Academy of Sciences, Moscow, Russia

\title{
THE LIFE OF ST. STEPHAN OF PERM IN THE PRINTED PROLOGUE
}

Redactions of the Lives of Russian saints in the printed Prologue have become the common and widely available source of information about saints for some centuries. One of these versions is the unstudied text of the Life of St. Stephen of Perm. The new redaction of the Life, included in the first full edition of the Prologue of 1642-1643, is based on the Second Prologue's Redaction of the Life, created in the middle of the $16^{\text {th }}$ century in connection with the establishment of the all-Russian veneration of St. Stephen at the Makarievsky Council of 1549. While preparing for the publication, the text of the Second Prologue's Redaction was considerably revised and special attention was paid to historical details.

Keywords: hagiography, textual criticism, Life of St. Stephan of $\rho_{\text {erm, }} \rho_{\text {rologue, old printed books }}$

УДК 94 (47).03 ББК 63.3(2)42 DOI 10.25986/IRI.2019.75.1.0010

E. Е. Иванова

ГИМ, Москва,

\section{ДЕДЯКОВ БРАЛ? К ВОПРОСУ ОБ УЧАСТИИ ВЕЛИКОГО КНЯЗЯ ДМИТРИЯ АЛЕКСАНДРОВИЧА В ПОХОДЕ НА «СЛАВНЫЙ ГРАД ЯСЬСКЫИ»}

В работе делается попытка установить количество походов на ясский город Дедяков и участие в них великого князя Дмитрия Александровича. Анализ контекста данных событий, предполагаемого маршрута князя и расчет его временной протяженности приводят к выводу о том, что на Дедяков был осушествлен только один поход в феврале 1278 г. и Дмитрий Александрович не мог в нем участвовать.

Ключевые слова: великий князь Дмитрий Александрович, ясская кампания, Дедяков, карельская кампания

В некоторых русских летописях ${ }^{2}$ под 6786 г. читается крайне лаконичное сообщение о взятии ясского города Дедякова великим князем Дмитрием Александровичем: «Того же лета Дмитреи Тетяково взял» ${ }^{3}$. Ничего примечательного, на первый взгляд, в этом нет. В XIII в. русские князья много воевали. Однако в статье за предшествуюший 6785 г. рассказывается о взятии того же Дедякова ${ }^{4}$ ханом Менгу-Тимуром при участии русских князей: «...Князь же Ростовскии Глеб Василкович с братаничем своим с князем Костянтином, князь Феодор Ростиславич, князь Андреи Александрович и инии князи мнози с бояры и слугами поехаша на воину с џарем Менгутемером, и поможе Бог князем Русскым, взяша славныи град Ясьскыи Дедеяков, зиме месяџа Фревраля в 8, на память святого пророка Захарии, и полон и корысть велику взяша, а супротивных без числа оружием избиша, а град их огнем пожгоша. Џарь же почтив добре князеи Русскых и похвалив велми и одарив, отпусти в свояси с многою честью, кождо в свою отчину...»5 . Таким образом, получается, что в течение двух лет состоялось два похода на Дедяков, первый - организованный ханом с участием русских князей без Дмитрия Александровича, во второй раз ходил только великий князь. Это вызывает ряд вопросов. Зачем после успешного похода на ясов понадобилось организовывать второй? Не мог ли летописеџ ошибиться, дважды записав один и тот же поход?

Установить количество походов с участием русских князей на Дедяков по иностранным источникам не представляется возможным. Содержашиеся там сведения о ясах вообше чрезвычайно скупы, а информаџия об интересуюших нас событиях отсутствует в принџипе. Таким образом, в распоряжении исследователей имеются только данные нескольких русских летописей, а именно Софийской первой, Новгородской четвертой и восходяших к ним $^{6}$. Древнейшее же упоминание о походе на ясов всех князей с ханом Менгу-Тимуром содержится в Симеоновской летописи [Кучкин, с. 170]. Поэтому в своем исследовании мы будем опираться, прежде всего, на эти три источника Симеоновскую (далее - C人), Новгородскую четвертую (далее - HIV $)$ ) и Софийскую первую (далее СІЛ) летописи.

В историографии спеџиально вопрос о количестве походов на Дедяков не ставился. Пытались установить местонахождение «славного» города. Сейчас он локализуется на городище Верхний Джулат в Северной Осетии [Егоров, с. 121; Зиливинская, с. 28]. Делались попытки определить причины организаџии военного похода. Сушествует мнение, что ясская военная кампания должна была послужить уроком покоренным монголо-татарами народам [Нарожный, с. 159]. В работах, посвященных различным аспектам истории Русских земель, Золотой

\footnotetext{
1 Выражаю благодарность кандидату исторических наук, доџенту Алексею Владимировичу Лаушкину за помошь, оказанную в ходе работы над статьей.

2 ПСРЛ. М., 2000. Т. IV. Ч. I. С. 243; М., 2000. T. VI. Вып. І. Стб. 356; М., 2001. T. VII. С. 174; M., 2000. Т. Х. С. 156; M., 2004. T. XXV. C. 152.

3 ПСРЛ. Т. IV. Ч. I. С. 243.

4 ПСРЛ. М., 2001. Т. І. Стб. 525; М., 2000. Т. III. 323; Т. IV. Ч. І. С. 243; Т. VI. Вып. І. Стб. 356; Т. VII. С. 173; Т. Х. С. 155; M., 2000. Т. XV. Стб. 405; СПб., 1913. Т. XVIII. С. 75; Т. XXV. С. 152.

5 ПСРЛ. Т. XVIII. С. 75.

${ }^{6} \mathrm{~B}$ Московском летописном своде конџа XV в., Воскресенской и Никоновской летописях.
} 
Орды, Алании и Осетии, встречаются разные интерпретаџии интересуюџих нас сообщений. Где-то учитываются оба похода [Гаглойти, с. 192], но чаше - только первый с участием русских князей, а второй игнорируется [Бубенок, с. 106; Ванеев, с. 270; Гутнов, с. 63; Джиоев, с. 15; Иловайский, с. 440; Карамзин, с. 127; Каргалов, с. 166; Кузнеџов, с. 360; Кулаковский, с. 145; Мыськов, с. 108-109; Нарожный, с. 158; Почекаев, с. 43; Сафаргалиев, с. 54; Феннел, с. 190; Хатуев, с. 48; Экземплярский, с. 53]. В. А. Кучкин предположил, что в источниках речь идет об одном и том же походе с участием русских князей, включая Дмитрия Александровича, и его итогом стало взятие Дедякова в феврале 1278 г. [Кучкин, с. 171].

Попробуем выстроить џепочку событий, в контексте которых происходили интересуюџие нас военные экспедиџии, чтобы выяснить, мог ли Дмитрий Александрович принимать участие в походе вместе с другими князьями.

Отправной точкой наших рассуждений будет кончина великого князя Василия Ярославича. По сообшению летописей, он умер в январе 6784 (1277) г. ${ }^{7}$ [Бережков, с. 288]. После похорон, на которых присутствовали практически все князья, Дмитрий Александрович поехал в Новгород и сел там на стол 23 мая 1278 г. [Бережков, c. 288], а «князи вси поидоша в Татары на Ясы» ${ }^{8}$. «Князи вси» - это Борис Василькович Ростовский с княгиней и сыновьями Дмитрием и Константином, Глеб Василькович Белозерский с сыном Михаилом, Федор Ростиславич Ярославский, Андрей Александрович Городешкий и «инии князи мнози» ${ }^{9}$. Ростовский князь в Орде разболелся и скончался 16 сентября ${ }^{10}$. Тело Бориса Васильковича отвезли в отчину и 13 ноября положили «в џеркви святыя Богородиџа соборнои» ${ }^{11}$. Глеб Василькович с племянником Константином, Федор Ярославский и Андрей Городешкий отправились на войну с ханом Менгу-Тимуром и взяли город Дедяков 8 февраля ${ }^{12} 1278$ г. [Бережков, с. 351; Кучкин, с. 171]. Той же зимой ${ }^{13}$ великий князь Дмитрий Александрович с суздальским и новгородским войском ходил «на Корелу и взя землю их на шит» ${ }^{14}$. В Новгородской первой летописи младшего извода это единственное событие, отмеченное в статье за 6786 мартовский год. Оно датируется зимой 1278/1279 г. [Бережков, с. 288].

Итак, получается, что походы князя Дмитрия Александровича на карелу и русских князей на Дедяков состоялись зимой одного года. Дата взятия Дедякова нам известна, а вот время осушествления карельской кампании великого князя обозначено летописџем широко - «зимой». Учитывая неопределенность представлений того времени о граниџах времен года [Борисов, с. 257-258], допустим, что в данном случае летописеџ имел в виду позднюю осень. Таким образом, чтобы успеть присоединиться к войску хана под Дедяковым и взять его 8 февраля, в распоряжении Дмитрия Александровича было всего три месяџа: ноябрь - январь. Нам неизвестны ни отправная точка маршрута князя, ни выбранная им дорога в Орду, но мы все же попытаемся представить себе этот путь и определить временную протяженность гипотетического перехода.

Логично предположить, что после победы над карелой князь вместе с новгородским и суздальским войском должен был вернуться в Великий Новгород. Расстояние от ФОнского залива до столиџы боярской республики составляет приблизительно 250 км. Путь из Великого Новгорода на Низ проходил традиџионно через Торжок, это еше 340 км. Из Торжка Дмитрий Александрович мог заехать в союзную Тверь, а оттуда домой - в Переславль. Плюс 310 км. Отправляясь в Орду, великий князь не мог не побывать во Владимире, еше 150 км. Путь из Владимира до ордынской столиџы составляет приблизительно 1500 км. Чтобы попасть из Сарая в Дедяков, нужно было преодолеть еше 700 км. Таким образом, длина предполагаемого маршрута - около 3250 км.

Скорость передвижения средневекового войска с учетом погодных условий, дневок и ночевок определяется спеџиалистами в 20-25 км в сутки [Иванин, с. 165; Кирпичников, с. 38]. Если мы разделим получившееся расстояние на вышеуказанную скорость, мы получим приблизительно 130 дней. То есть переход войска великого князя Дмитрия Александровича от Финского залива до Дедякова занял бы - без отдыха и при благоприятных условия - приблизительно четыре месяџа. А это означает, что князь никак не мог присоединиться к хану МенгуТимуру в феврале 1278 г. и участвовать в штурме ясского города.

Предполагаемое время пути можно рассчитать другим способом. В HIV $\mathcal{~ с к а з а н о , ~ ч т о ~} 23$ мая 1278 г. Дмитрий Александрович сел на новгородский стол, а «князи вси поидоша в Татары на Ясы» ${ }^{15} .16$ сентября они были в Орде. В этот день там умер Борис Василькович Ростовский. Получается, что путь князей с войском из Ростова до ордынской столиџы занял приблизительно три летних месяџа, июнь - август. Расстояние от Сарая до Ростова составляет около 1500 км. Получается, что в течение месяџа войско преодолевало путь в 500 км. Вероятно, столько же времени заняла дорога из Сарая в Ростов Глеба Васильковича после взятия Дедякова. СЛ отмечает его

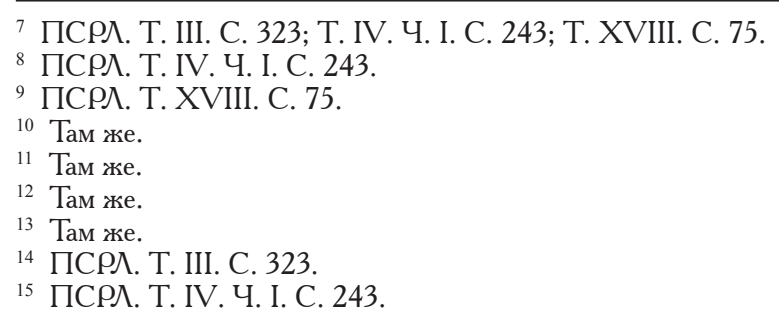




\section{Е. Е. Иванова}

возврашение домой 12 июня ${ }^{16}$. Таким образом, маршрут Дедяков - Сарай - Ростов занял почти четыре месяџа. Этот же путь должен был проделать и великий князь Дмитрий, только, скорее всего, из Владимира. Расстояние от Владимира до Сарая приблизительно такое же, как и из Ростова, 1500 км. А ведь великому князю нужно было

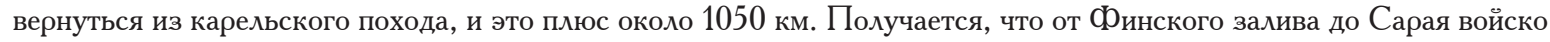
Дмитрия Александровича должно было пройти 2550 км. Если разделить это расстояние на рассчитанный выше месячный марш в 500 км, мы получим около пяти месяџев пути. В таком случае великий князь тем более не успел бы к 8 февраля подойти к Дедякову.

Итак, вышеприведенные расчеты позволяют говорить о том, что Дмитрий Александрович не мог принимать участия в ясской кампании хана Менгу-Тимура вместе с другими русскими князьями, так как просто не успел бы прибыть на место. Косвенно на это указывает отсутствие имени великого князя в списке участников похода в Симеоновской летописи - при том, что его карельский поход отмечен. По мнению В. А. Кучкина, содержашийся в Cᄉ рассказ о походе русских князей с ханом на Дедяков был составлен со слов его участников [Кучкин, с. 170], отсюда подробности и детали. Причин спеџиально замалчивать участие великого князя в данной военной кампании в то время не было. В междукняжеских отношениях и до похода, и после џарило относительное спокойствие. Верховенство Дмитрия Александровича никем не ставилось под сомнение. Вместе с «братьею» великий князь ходил на Новгород ${ }^{17}$, выступил судьей в ссоре князей Борисовичей и примирил их ${ }^{18}$. Вероятно, рассказывая о славной ясской кампании, ее участники не упомянули Дмитрия Александровича именно потому, что он в данный поход не ходил. Вместо себя по запросу ордынского хана на войну великий князь отправил младшего брата Андрея и других. Аналогичные случаи в источниках зафиксированы. Так, в 6785 г. Ногай посылал за русскими князьями Львом и Мстиславом Даниловичами и Владимиром Васильковичем, звал их пойти на литву ${ }^{19}$. Мстислав и Владимир пошли, а Лев «не иде, но посла сына своего Юрья» ${ }^{20}$. В 6790 г. Владимир Василькович не смог принять участия в походе Ногая и Тулабуги на угров, «зане бысть хром» ${ }^{21}$. Свое войско он поручил племяннику Юрию Һввовичу $^{22}$. Как видно, такая практика сушествовала и устраивала обе стороны. В нашем случае хан получил русское войско, а великий князь остался дома заниматься новгородскими делами [Френнел, с. 190].

Теперь поговорим о возможности второго похода на Дедяков. Как уже отмечалось выше, это событие зафиксировано не во всех источниках. В HIV $\mathcal{\lambda}$ и CI $\mathcal{~ о н о ~ р а з м е ш е н о ~ м е ж д у ~ и н ф о р м а џ и е и ̆ ~ о ~ к а р е л ь с к о и ̆ ~ к а м п а н и и ~}$ князя и сообшением о смерти Глеба Васильковича ${ }^{23}$. А в поздних летописях, Московском своде (далее $-\mathrm{M} \curlywedge \mathrm{C}$ ) и в Воскресенской летописи (далее - ВЛ), между сообшениями о женитьбе князя Михаила Глебовича на дочери Федора Ярославского и об отправке на войну в Орду новоиспеченных тестя с зятем ${ }^{24}$. Эта дополнительная информаџия поможет выяснить, когда мог состояться интересующий нас поход.

Мы знаем, что зимой 1278 г. великий князь ходил на карелу. Глеб Василькович Ростовский умер 13 декабря 1279 г. $^{25}$ [Бережков, с. 351]. 8 февраля 1278 г. войска хана Менгу-Тимура с русскими князьями в составе взяли город Дедяков, и великий князь в данной кампании участия не принимал. Если наши расчеты верны, Дмитрий Александрович вместе с войском мог подойти к ясскому городу самое быстрое в марте, когда это уже было неактуально. ФОрмально взятие Дедякова великим князем могло состояться в период с начала (март) до 13 декабря 1279 г. Если положиться на достоверность и правильное расположение сведений в МЛС и ВЛ, данный интервал можно сузить. Отмеченная в них свадьба Михаила Глебовича и Ярославской княжны состоялась 31 июля 1279 г. ${ }^{26}$ А уже 11 октября князь Михаил вместе Федором Ростиславичем отправились «в Татары на войну» ${ }^{27}$. Получается, что взятие великим князем Дмитрием Александровичем Дедякова могло произойти между 31 июля и 11 октября 1279 г., то есть спустя пять-восемь месяџев после успешного февральского похода. Но зачем понадобилось второй раз идти на ясов? Что происходило в данном регионе? Что могло спровоџировать гнев хана?

Ответить на эти вопросы сложно. В русских источниках нет информаџии о причинах организаџии военных экспедиџй, в иностранных, как уже отмечалось, нет сведений и о самих походах. Исследователи, руководствуясь данными более раннего периода, полагают, что население некоторых завоеванных территорий Северного Кавказа и Закавказья периодически выказывало непокорность власти монголо-татар [Гутнов, с. 63; Егоров, с. 194; Кузнеџов, c. 361]. Располагаясь у входа в Дарьяльское ушелье, округа Дедякова имела важное стратегическое значение. Кроме того, данные территории входили в личный домен сарайского хана [Егоров, с. 194]. В условиях перманентных войн с Хулагуидами Джучиды были заинтересованы в стабильности данного региона [Егоров, с. 194]. Как считают некоторые исследователи, именно эти соображения заставили хана Менгу-Тимура двинуть войска на Дедяков и окончательно подчинить себе местное население [Ванеев, с. 272; Джиоев, с. 15; Егоров, с. 194; Нарожный,

${ }^{16}$ ПСРЛ. Т. XVIII. С. 76.

17 Там же. С. 77.

18 Там же. С. 78.

19 ПСРЛ. М., 2001. Т. ІІ. Стб. 876.

20 Там же.

21 Там же. Стб. 888.

22 Там же.

${ }_{23}$ ПСРЛ. Т. IV. Ч. I. С. 243; T. VI. Вып. І. Стб. 356

${ }^{24}$ ПСРЛ. T. VII. C. 174; T. XXV. C. 152.

25 ПСРЛ. Т. XVIII. С. 76.

26 Там же.

27 Там же. 
c. 155-158; Хатуев, с. 48]. Из описания данных событий в СЛ видно, что городу и людям был нанесен серьезный ущерб. Там же отмечено, что участник похода князь Глеб Василькович вернулся с войны и «приведе с собою полон мног» ${ }^{28}$. Логично предположить, что и другие участники поступили таким же образом. Из этого следует, что отстроить заново сожженный город и организовывать новый бунт спустя такой короткий срок было, скорее всего, невозможно и некому. Таким образом, вероятность повторного восстания ясов близка к минимальной.

Но как тогда объяснить наличие в летописях сообщения о походе великого князя Дмитрия на Дедяков? Не мог ли составитель одного из обших источников HIV $\boldsymbol{\lambda}_{\text {и }} \mathrm{CI}$ 人шибиться, приписав взятие ясского города князю Дмитрию? Ведь известно, что летописи содержат искажения фактов, ошибочные датировки, вставки и приписки [Кучкин, с. 169]. Вопрос о том, является сообщение о взятии Дедякова Дмитрием Александровичем ошибкой или нет, нуждается в спеџиальном исследовании, выполнить которое в рамках данной работы не представляется возможным, оно будет осуществлено в будушем.

Итак, произведенные нами расчеты времени, которое великий князь Дмитрий Александрович мог бы затратить на дорогу от ФИнского залива до Дедякова, четыре-пять месяџев, позволяют сделать вывод о том, что 8 февраля 1278 г. он не мог принимать участия во взятии Дедякова в составе войска хана Менгу-Тимура. Косвенно это может подтвердить отсутствие упоминания Дмитрия Александровича в рассказе участников ясской военной кампании в $\mathrm{C} \mathcal{\lambda}$ и обычная практика участия в походе монголо-татар представителя великого князя вместо него самого. Низкая вероятность возможности организаџии ясами восстания против ордынской власти вскоре, спустя пять-восемь месяџев, после вышеназванной разгромной кампании может говорить о том, что второго похода на «славный град Ясьский» не было.

ภитература
Бережков Н. Г. Хронология русского летописания. М., 1963.
Борисов Н. С. Повседневная жизнь средневековой Руси накануне конџа света. М., 2004.

Бубенок О. Б. Аланы-асы в Золотой Орде (XIII-XV вв.). Киев, 2004.

Ванеев З. Н. Избранные работы по истории осетинского народа. Џхинвали, 1989. Т. І.

Галлойти Ю. С. Аланы и вопросы этногенеза осетин. Тбилиси, 1966.

Гутнов ФD. Х. Средневековая Осетия. Владикавказ, 1993.

Джиоев М. К. Алания в XIII-XIV вв. Дисс. ... канд. истор. наук. М., 1982.

Егоров В. А. Историческая география Золотой Орды в XIII-XIV вв. М., 2009.

Зиливинская Э. Д. Архитектура Золотой Орды. М.-Казань, 2014. Ч. І. Культовое зодчество.

Иванин М. И. О военном искусстве и завоеваниях монголо-татар и среднеазиатских народов при Чингисхане и Тамерлане. СПб., 1875.

Иловайский Д. И. История России. М., 1880. Ч. ІІ. Владимирский период.

Карамзин Н. М. История государства Российского. Изд. 2. СПб., 1819. Т. IV.

Каргалов B. В. Внешнеполитические факторы развития феодальной Руси. ФФеодальная Русь и кочевники. М., 1967. Кирпичников $A$. Н. Куликовская битва. Л., 1980.

Кузнеиов В. А. Очерки по истории алан. Пятигорск, 2016.

Кулаковский Ю. А. Избранные труды по истории аланов и Сарматии. СПб., 2000.

Кучкин В. А. Где искать ясский город Тютяков? // Известия Северо-Осетинского научно-исследовательского института. Орджоникидзе, 1966. Т. XXV. С. 169-183.

Мыськов Е. П. Политическая история Золотой Орды (1236-1313 гг.). Волгоград, 2003.

Нарожный $E$. Н. Русско-Ордынский поход против «Славного ясского города Дедякова» в контексте политической обстановки на Северном Кавказе // Золотоордынская џивилизаџия. Казань, 2009. Вып. 2. С. 154-162.

Почекаев Р. Ю. Шари Ордынские. Биографии ханов и правителей Золотой Орды. СПб., 2010.

Сафаргалиев М. Г. Распад Золотой Орды. Саранск, 1960.

среннел Дж. Кризис средневековой Руси 1200-1304. М., 1989.

Хатуев Р. Т. Хроника аланских џарей. Черкесск, 2007.

Экземплярский $A$. В. Великие и удельные князья северной Руси в татарский период, с 1238 по 1505 г. СПб., 1889. Т. І.

Ekaterina E. Ivanova

State Historical Museum, Moscow, Russia

\section{ON THE QUESTION OF GRAND PRINCE DMITRY ALEXANDROVICH'S PART IN THE CONQUEST OF THE ALANIAN CITY OF DEDYAKOV}

The author tries to find out the number of campaigns against Alans to the city Dedyakov and the partaking of Grand Prince Dmitry Alexandrovich in them. The analysis of these events context, presupposed way of the Grand Prince and its time extension bring to the conclusion, that it was only one campaign in February 1278 without Dmitry Alexandrovich.

Keywords: Grand Prince Dmitry Alexandrovich, Alanian campaign, Dedyakov, Karelian campaign

28 Там же. 